\title{
KETEPATAN PENGEMBALIAN REKAM MEDIS PASIEN RAWAT INAP DI RUMAH SAKIT MITRA SIAGA TEGAL
}

\author{
Amalia Dina Rosalin ${ }^{1}$, Leni Herfiyanti ${ }^{2}$ \\ Politeknik Piksi Ganesha, Bandung, Indonesia ${ }^{1,2}$ \\ amaliadinarosalin@gmail.com1 ${ }^{1}$, leniherfiyanti@gmail.com ${ }^{2}$
}

Received: 26-06-2021

Revised : 07-07-2021

Accepted: 25-07-2021

\begin{abstract}
Abstrak
Latar Belakang: Ketepatan pengembalian berkas rekam medis di rumah sakit merupakan salah satu unsur yang mempengaruhi kualitas kinerja unit rekam medis serta pelayanan di rumah sakit. Berdasarkan Standar Prosedur Operasional (SPO) di rumah Sakit Mitra Siaga dan Peraturan Pemerintah standar waktu pengembalian rekam medis adalah $2 \times 24$ jam setelah pasien pulang.

Tujuan: Tujuan penelitian ini dilakukan untuk mengetahui tingkat ketepatan pengembalian rekam medis pasien rawat inap.

Metode: Penelitian ini menggunakan teknik pendekatan kualitatif dengan metode observasi partisipatif dan pengambilan jumlah sampel menggunakan rumus slovin. Dari populasi 1.131 rekam medis pasien rawat inap bulan Maret 2021 yang diteliti pada bulan April 2021, peneliti mengambil sampel sebanyak 92 rekam medis sesuai hasil perhitungan menggunakan rumus slovin dengan tingkat kesalahan $10 \%$.

Hasil: Dari hasil penelitian, sebanyak 25 rekam medis atau sebanyak 23\% dikembalikan tepat waktu dan 67 rekam medis (77\%) dikembalikan dengantidak tepat waktu.

Kesimpulan: Maka dari hasil tersebut persentase pengembalian rekam medis tidak tepat waktu masih lebih tinggi dari pada angka persentase rekam medis yang dikembalikan tepat waktu. Keterlambatan pengembalian rekam medis dipengaruhi oleh berbagai faktor salah satunya kedisiplinan pihak terkait dalam pelengkapan rekam medis dan juga alur pengembalian rekam medis yang tidak langsung dikembalikan ke unit rekam medis setelah pasien pulang.

Kata kunci: pengembalian; rekam medis; rawat inap.
\end{abstract}

\begin{abstract}
Background: The accuracy of returning medical record files at the hospital is one of the elements that affect the quality of the performance of the medical record unit and services at the hospital. Based on Standard Operating Procedures (SPO) at Mitra Siaga Hospital and Government Regulations, the standard time for returning medical records is $2 \times 24$ hours after the patient returns home.
\end{abstract}

Objective: The purpose of this study was to determine the 
level of accuracy in returning inpatient medical records.

Methods: This study uses a qualitative approach with participatory observation methods and taking the number of samples using the slovin formula. From a population of 1,131 medical records of hospitalized patients in March 2021 which was studied in April 2021, researchers took a sample of 92 medical records according to the results of calculations using the Slovin formula with an error rate of $10 \%$.

Results: From the results of the study, as many as 25 medical records or as much as $23 \%$ were returned on time and 67 medical records (77\%) were not returned on time.

Conslusion: So from these results the percentage of medical record returns that are not on time is still higher than the percentage of medical records that are returned on time. The delay in returning medical records is influenced by various factors, one of which is the discipline of related parties in completing medical records and also the flow of returning medical records which are not immediately returned to the medical record unit after the patient returns home.

Keywords: return; medical records; inpatient.

Coresponden Author : Amalia Dina Rosalin

Email : amaliadinarosalin@gmail.com

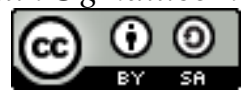

\section{PENDAHULUAN}

Berdasarkan Undang-undang Nomor 44, 2009 tentang rumah sakit, Rumah Sakit adalah institusi pelayanan kesehatan yang menyelenggarakan pelayanan kesehatan perorangan secara paripurna yang menyediakan pelayanan rawat inap, rawat jalan, dan gawat darurat (Indonesia, 44 C.E.). Fungsi rumah sakit adalah penyelenggaraan pelayanan pengobatan dan pemulihan kesehatan sesuai dengan standar pelayanan rumah sakit (Kemendagri, 2009).

Menurut Peraturan Menteri Kesehatan Nomor 269/MENKES/PER/III/2008 Rekam medis adalah berkas yang berisiskan catatan dan dokumen tentang identitas pasien, pemeriksaan, pengobatan, tindakan dan pelayanan yang telah diberikan kepada pasien (Menkes, 2008). Menurut (Hutagaol \& Sakit, n.d.) isi rekam kesehatan dibagi dalam data administratif dan data klinis, sedangkan isi (data atau informasi) rekam kesehatan dipengaruhi oleh bentukpelayanan kesehatan, bentuk klasifikasi jenis pelayanan, serta bentuk status kepemilikan sarana kesehatan.

Menurut (Endradita et al., 2019) Rawat inap adalah istilah yang berarti proses perawatan pasien oleh tenaga kesehatan profesional akibat penyakit tertentu, dimana pasien diinapkan di suatu ruangan di rumah sakit.

Menurut (Fadhilah, 2018) Peraturan Menteri Kesehatan Nomor 269/MENKES/PER/III/2008 Pasal 3 Hal 3 bahwa isi rekam medis untuk pasien rawat inap sekurang-kurangnya memuat identitas pasien, tanggal dan waktu, hasil anamnesa mencakup sekurang-kurangnya keluhan dan riwayat penyakit, hasil pemeriksaan fisik dan penunjang medik, diagnosa, rencana penatalaksanaan, persetujuan tindakan bila diperlukan, catatan observasi klinis dan hasil pengobatan, ringkasan pulang, nama dan tanda tangan dokter, atau tenaga kesehatan tertentu yang memberikan pelayanan 
kesehatan, Pelayanan lain yang dilakukan oleh tenaga kesehatan tertentu, dan Untuk pasien khusus gigi dilengkapi dengan odontogram klinik.

Menurut Peraturan Menteri Kesehatan Nomor 269/MENKES/PER/III/2008 Pasal12 menyatakan bahwa isi rekam medis adalah milik pasien, pasal1 ayat (2) sedangkan berkas rekam medis secara fisik adalah milik rumah sakit atau institusi kesehatan tersebut. Apabila pasien membutuhkan berkas rekam medis, maka dapat diberikan isinya dengan cara dicatat atau diphotocopy oleh pasien, pasal 2 ayat (4) (Permenkes, 2008).

Menurut (Depkes, 2006) karena pentingnya kegunaan rekam medis dan karena keterlambatan waktu pengembalian rekam medis maka mempersulit pelaksanaan petugas assembling dan coding. Maka dari itu berkas rekam medis pasien dikembalikan ke unit rekam medis paling lambat $2 \times 24$ jam setelah pasien pulang secara lengkap dan benar.

Menurut wikipedia asuransi kesehatan adalah sebuah jenis produk asuransi yang secara khusus menjamin biaya kesehatan atau perawatan para anggota asuransi tersebut jika mereka jatuh sakit atau mengalami kecelakaan.

Masih sering terjadinya keterlambatan pengembalian rekam medis yang berharihari atau lebih dari $2 \times 24$ jam setelah pasien pulang. Jumlah rekam medis yang dikembalikan ke bagian assembling dalam sebulan ada 1.131 berkas rekam medis dari 14 bangsal perawatan.

Penyebab keterlambatan pengembalian rekam medis pasien rawat inap yaitu kedisiplinan pihak terkait dalam pelengkapan rekam medis dan juga proses pengklaiman asuransi di bagian pengendali yang sangat lama karena banyaknya pasien.

Dan keterlambatan juga terkait dengan alur pengembalian rekam medis ke unit rekam medis karena setelah pasien pulang dan rekam medis sudah dilengkapi oleh pihak terkait rekam medis langsung menuju bagian pengendali untuk pengecekan ulang jika rekam medis lengkap maka langsung masuk proses untuk pengklaiman jika rekam medis tidak lengkap maka dikembalikan ke ruang perawatan untuk dilengkapi seteah lengkap maka rekam medis tersebut masuk ke proses pengklaiman setelah pengklaiman selesai baru rekam medis dikembalikan ke unit rekam medis untuk di assembling dan kemudian diinput kedalam simrs dan kemudian masuk ke ruang filing.

Oleh karena itu penelitian ini dilakukan untuk mengetahui sebab dan akibat dari keterlambatan pengembalian rekam medis pasien rawat inap di Rumah Sakit Mitra Siaga Tegal.

\section{METODE PENELITIAN}

Penelitian ini menggunakan pendekatan kualitatif. Data dikumpulkan selama 1 bulan pada Maret 2021 di Rumah sakit Mitra Siaga Tegal. Data dikumpulkan melalui observasi partisipatif yakni peneliti terlibat dengan kegiatan sehari-hari selagi melakukan pengamatan peneliti juga ikut melakukan apa yang dikerjakan oleh sumber data dan wawancara kepada pegawai yang terkait secara purposive yakni informan dipilih dengan pertimbangan dan tujuan tertentu. Informan yang terkait dalam penelitian ini adalah kepala unit rekam medis RS Mitra Siaga, petugas pelaporan dan pengolahan data, petugas assembling, coder, serta petugas filing yang ada di rumah sakit.

Sumber data dalam penelitian ini dibagi menjadi sumber primer dan sumber sekunder. Sumber primer berupa hasil dari wawancara mendalam, observasi, dan telaah dokumen. Sedangkan sumber sekunder berupa data-data yang diperoleh guna melengkapi hasil penelitian.

Populasi dalam penelitian ini adalah seluruh rekam medis pasien rawat inap pada bulan Maret 2021 di RS Mitra Siaga Tegal sebanyak 1.131.

Besar sampel dalam penelitian ini menggunakan rumus slovin dengan tingkat kesalahan $10 \%$ dan jumlah populasi sebanyak 1.131 rekam medis yang berasal dari 
jumlah pasien rawat inap di bulan Maret 2021. Berikut hasil perhitungan sampel menggunakan rumus slovin :

$$
\begin{gathered}
n=\frac{N}{1+N e^{2}} \\
n=\frac{1.131}{1+1.131(0,1)^{2}} \\
n=\frac{1.131}{1+1.131 * 0,01} \\
n=\frac{1.131}{1+11,31} \\
n=\frac{1.131}{12,31} \\
n=91,8 \\
n=92
\end{gathered}
$$

Sehingga jumlah rekam medis rawat inap yang diteliti sebanyak 92 rekam medis.

\section{HASIL DAN PEMBAHASAN}

\section{A. Hasil Penelitian}

Unit rekam medis RS Mita Siaga Tegal dipimpin oleh kepala unit rekam medis yang berada di bawah manajer pelayanan dan penunjang. Dalam tugasnya kepala unit rekam medis dibantu oleh bagian pendaftaran,bagian pelaporan, bagian assembling, bagia nkoding,bagian filing serta bagian distribusi. Setiap bagiannya mempunyai tugasnya masing-masing.

Dalam penanganan berkas rekam medis pasien pulang berkas diantarkan ke unit rekam medis oleh dropper. Perawat unit rawat inap hanya melengkapi berkas rekam medis setelah berkas rekam medis lengkap dikembalikan ke unit rekam medis lalu berkas tersebut diassembling, setelah itu dikodingdan diinput kedalam SIMRS lalu diserahkan kepada bagian filing (Jefriany, 2017).

"Disini setelah pasien pulang rekam medis ada di ruangan perawat ruang rawat inap untuk dilengkapi lalu dikembalikan ke unit rekam medis bersama buku statusnya oleh dropper" (informan 1).

Kelengkapan berkas rekam medis sangat berpengaruh terhadap ketepatan pengembalian. Berdasarkan hasil observasi terdapat banyak berkas rekam medis yang kembali lebih dari 2x24 jam karena proses pelengkapan berkas rekam medis oleh perawat dan ada juga berkas rekam medis yang setelah pasien pulang yang menggunakan BPJS rekam medis dibawa ke ruang pengendali untuk proses pengklaiman biaya perawatan sehingga berkas terlambat dikembalikan ke unit rekam medis (Herfiyanti, 2019).

"Untuk waktu pengembalian rekam medis di sini sangat variatif tergantung ruang rawat inapnya ada ruangan yang tepat waktu ada juga yang lama dikembalikan" (informan 2).

Dalam pengembalian rekam medis rawat inap di RS Mitra Siaga waktu yang di butuhkan berbeda-beda setiap ruangannya. Tidak semua ruang rawat inap telat untuk mengembalikan rekam medisnya masih ada beberapa rekam medis yang kembali ke unit rekam medis kurang dari $2 \times 24$ jam.

Faktor keterlambatan rekam medis dikembalikan ke unit rekam medis yaitu pelengkapan rekam medis oleh perawat yang tidak langsung dilengkapi setelah pasien pulang. Sehingga rekam medis tertahan di ruang rawat inap dan pengembalian bisa sampai 3-4 hari setelah pasien pulang (Hasibuan, 2020). 
Selain tertahan di ruang rawat inap rekam medis juga terkadang tertahan di pengendali. Fungsi pengendali di rumah sakit Mitra Siaga yaitu untuk pengklaiman BPJS maupun asuransi lain dan juga untuk perincian biaya pasien non asuransi. Di pengendali rekam medis di lihat kelengkapannya ataupun masalah yang terkit dengan asuransi. Setelah rekam medis selesai untuk pengklaiman dikembalikan ke unit rekam medis. Untuk waktu pengembaliannya bisa sampai 1 minggu setelah pasien pulang.

"Kadang kalau ada pasien post rawat inap mau kontrol waktu mau ambil berkasnya buat diantar ke poli bingung berkasnya ngga ada di ruang filingjadi harus cari berkasnya dulu" (informan 3)

Menurut (Winarti, 2013) keterlambatan pengambalian rekam medis rawat inap juga sangat berpengaruh untuk pelayanan rawat jalan. Ketika pasien post rawat inap datang ke rumah sakit untuk kontrol ketika pasien tersebut mendaftar dan berkas akan diantar oleh petugas filing ke poli berkas pasien tersebut tidak ada di ruang filing dan petugas harus menghubungi ruang rawat inap untuk mengkonfirmasi keberadaan rekam medis dan selanjutnya jika berkas tersebut masih di ruangan akan di titipkan kepada dropper untuk di antar ke unit rekam medis. Dengan begitu akan mempengaruhi pelayanan karena membutuhkan waktu untuk mencari rekam medis pasien tersebut (Janwarin \& Makmun, 2019).

Berdasarkan hasil perhitungan jumlah pengambilan sampel ada 92 berkas yang diteliti. Observasi dilakukan dengan cara penulis terjun langsung di kegiatan sehari-hari petugas rekam medis.

Berdasarkan dari hasil wawancara di atas keterlambatan pengembalian rekam medis disebabkan oleh lama nya pelengkapan rekam medis oleh perawat dan lamanya waktu pengklaiman asuransi di bagian pengendali untuk pasien yang menggunakan asuransi seperti BPJS, prudensial, dan asuransi lainnya.

Proses yang paling lama adalah di bagian pengendali. Berkas rekam medis rawat inap yang sudah dilengkapi oleh perawat langsung dibawa ke bagian pengendali untuk diteliti lagi. Jika ada berkas rekam medis yang masih belum lengkap maka dikembalikan ke perawat ruangan untuk dilengkapi kembali. Setelah rekam medis lengkap maka akan masuk proses klaim asuransi bagi pasien rawat inap yang menggunakan asuransi.

Tabel 1.

Sampel pengembalian rekam medis

\begin{tabular}{cccccll}
\hline No & No RM & $\begin{array}{c}\text { Tanggal } \\
\text { Masuk }\end{array}$ & $\begin{array}{c}\text { Tanggal } \\
\text { Keluar }\end{array}$ & $\begin{array}{c}\text { Tanggal } \\
\text { Kembali }\end{array}$ & Cara Bayar & $\begin{array}{c}\text { Keterlam } \\
\text { batan }\end{array}$ \\
\hline 1 & 201078 & $01-03-2021$ & $01-03-2021$ & $02-03-2021$ & UMUM & - \\
\hline 2 & 247639 & $01-03-2021$ & $04-03-2021$ & $12-03-2021$ & BPJS & 6 hari \\
\hline 3 & 250870 & $01-03-2021$ & $02-03-2021$ & $04-03-2021$ & BPJS & - \\
\hline 4 & 250178 & $01-03-2021$ & $03-03-2021$ & $04-03-2021$ & BPJS & - \\
\hline 5 & 251092 & $01-03-2021$ & $02-03-2021$ & $04-03-2021$ & BPJS & - \\
\hline 6 & 251094 & $01-03-2021$ & $06-03-2021$ & $09-03-2021$ & UMUM & 1 hari \\
\hline 7 & 167272 & $01-03-2021$ & $04-03-2021$ & $08-03-2021$ & BPJS & 2 hari \\
\hline 8 & 188953 & $01-03-2021$ & $02-03-2021$ & $13-03-2021$ & BPJS & 9 hari \\
\hline 9 & 226984 & $01-03-2021$ & $02-03-2021$ & $04-03-2021$ & UMUM & - \\
\hline 10 & 251098 & $01-03-2021$ & $03-03-2021$ & $04-03-2021$ & BPJS & - \\
\hline 11 & 250706 & $01-03-2021$ & $05-03-2021$ & $07-03-2021$ & BPJS & - \\
\hline 12 & 244410 & $01-03-2021$ & $02-03-2021$ & $04-03-2021$ & BPJS & - \\
\hline 13 & 192992 & $01-03-2021$ & $03-03-2021$ & $08-03-2021$ & BPJS & 3 hari \\
\hline 14 & 154632 & $03-03-2021$ & $05-03-2021$ & $06-03-2021$ & LAIN-LAIN & - \\
\hline 15 & 213564 & $01-03-2021$ & $03-03-2021$ & $05-03-2021$ & BPJS & - \\
\hline 16 & 251122 & $01-03-2021$ & $05-03-2021$ & $12-03-2021$ & BPJS & 5 hari \\
\hline
\end{tabular}




\begin{tabular}{|c|c|c|c|c|c|c|}
\hline No & No RM & $\begin{array}{l}\text { Tanggal } \\
\text { Masuk }\end{array}$ & $\begin{array}{l}\text { Tanggal } \\
\text { Keluar }\end{array}$ & $\begin{array}{l}\text { Tanggal } \\
\text { Kembali }\end{array}$ & Cara Bayar & $\begin{array}{c}\text { Keterlam } \\
\text { batan }\end{array}$ \\
\hline 17 & 198040 & 01-03-2021 & 04-03-2021 & 08-03-2021 & BPJS & 2 hari \\
\hline 18 & 095209 & $01-03-2021$ & $05-03-2021$ & 09-03-2021 & UMUM & 2 hari \\
\hline 19 & 229532 & 01-03-2021 & 04-03-2021 & 05-03-2021 & BPJS & - \\
\hline 20 & 251124 & 01-03-2021 & 03-03-2021 & 04-03-2021 & UMUM & - \\
\hline 21 & 251128 & 01-03-2021 & 03-03-2021 & 08-03-2021 & BPJS & 3 hari \\
\hline 22 & 250759 & 01-03-2021 & $02-03-2021$ & 14-03-2021 & BPJS & 10 hari \\
\hline 23 & 251119 & $01-03-2021$ & 04-03-2021 & 09-03-2021 & BPJS & 3 hari \\
\hline 24 & 148000 & 01-03-2021 & $07-03-2021$ & $08-03-2021$ & BPJS & - \\
\hline 25 & 251135 & $01-03-2021$ & 04-03-2021 & 12-03-2021 & BPJS & 6 hari \\
\hline 26 & 251138 & 01-03-2021 & 03-03-2021 & 05-03-2021 & UMUM & - \\
\hline 27 & 251145 & 01-03-2021 & 04-03-2021 & 08-03-2021 & BPJS & 2 hari \\
\hline 28 & 220649 & 01-03-2021 & 04-03-2021 & 11-03-2021 & BPJS & 5 hari \\
\hline 29 & 066484 & 01-03-2021 & $07-03-2021$ & 08-03-2021 & BPJS & - \\
\hline 30 & 129385 & 01-03-2021 & $06-03-2021$ & 07-03-2021 & BPJS & - \\
\hline 31 & 222910 & 01-03-2021 & $05-03-2021$ & 09-03-2021 & ASURANSI & 2 hari \\
\hline 32 & 240741 & 01-03-2021 & 03-03-2021 & 08-03-2021 & UMUM & 3 hari \\
\hline 33 & 251232 & 03-03-2021 & 04-03-2021 & $05-03-2021$ & BPJS & - \\
\hline 34 & 197936 & 01-03-2021 & 03-03-2021 & 09-03-2021 & BPJS & 4 hari \\
\hline 35 & 172971 & $01-03-2021$ & $02-03-2021$ & 05-03-2021 & BPJS & 1 hari \\
\hline 36 & 251147 & 01-03-2021 & 02-03-2021 & 05-03-2021 & UMUM & 1 hari \\
\hline 37 & 251151 & 01-03-2021 & 05-03-2021 & 08-03-2021 & BPJS & 1 hari \\
\hline 38 & 251152 & $01-03-2021$ & $02-03-2021$ & 04-03-2021 & UMUM & - \\
\hline 39 & 251153 & $01-03-2021$ & $02-03-2021$ & $09-03-2021$ & BPJS & 5 hari \\
\hline 40 & 251154 & 01-03-2021 & 02-03-2021 & 08-03-2021 & BPJS & 4 hari \\
\hline 41 & 251155 & 01-03-2021 & 04-03-2021 & 09-03-2021 & BPJS & 3 hari \\
\hline 42 & 251157 & $01-03-2021$ & $03-03-2021$ & $05-03-2021$ & UMUM & - \\
\hline 43 & 251158 & 02-03-2021 & 08-03-2021 & 08-03-2021 & BPJS & - \\
\hline 44 & 159234 & $02-03-2021$ & $04-03-2021$ & $08-03-2021$ & BPJS & 2 hari \\
\hline 45 & 251160 & $02-03-2021$ & 03-03-2021 & 09-03-2021 & BPJS & 4 hari \\
\hline 46 & 218855 & $02-03-2021$ & 03-03-2021 & 04-03-2021 & BPJS & - \\
\hline 47 & 130879 & 02-03-2021 & 03-03-2021 & 05-03-2021 & BPJS & - \\
\hline 48 & 251063 & $02-03-2021$ & 03-03-2021 & 04-03-2021 & BPJS & - \\
\hline 49 & 244338 & $02-03-2021$ & 04-03-2021 & 08-03-2021 & BPJS & 2 hari \\
\hline 50 & 251161 & $02-03-2021$ & $02-03-2021$ & 06-03-2021 & ASURANSI & 2 hari \\
\hline 51 & 153697 & $02-03-2021$ & $03-03-2021$ & $06-03-2021$ & BPJS & 1 hari \\
\hline 52 & 251164 & $02-03-2021$ & $02-03-2021$ & $05-03-2021$ & BPJS & 1 hari \\
\hline 53 & 251166 & 02-03-2021 & 05-03-2021 & 08-03-2021 & UMUM & 1 hari \\
\hline 54 & 183915 & $02-03-2021$ & 04-03-2021 & 08-03-2021 & ASURANSI & 2 hari \\
\hline 55 & 251173 & $02-03-2021$ & $05-03-2021$ & $25-03-2021$ & UMUM & 18 hari \\
\hline 56 & 251121 & 02-03-2021 & 02-03-2021 & $05-03-2021$ & BPJS & 1 hari \\
\hline 57 & 251175 & $02-03-2021$ & $06-03-2021$ & $09-03-2021$ & BPJS & 1 hari \\
\hline 58 & 199818 & 02-03-2021 & 04-03-2021 & 08-03-2021 & BPJS & 2 hari \\
\hline 59 & 251249 & $03-03-2021$ & $04-03-2021$ & $08-03-2021$ & LAIN-LAIN & 2 hari \\
\hline 60 & 251252 & $03-03-2021$ & $03-03-2021$ & $08-03-2021$ & Umum & 3 hari \\
\hline 61 & 251178 & $02-03-2021$ & $04-03-2021$ & $08-03-2021$ & ASURANSI & 2 hari \\
\hline 62 & 224664 & $02-03-2021$ & $06-03-2021$ & 06-03-2021 & BPJS & - \\
\hline 63 & 251181 & $02-03-2021$ & 05-03-2021 & 14-03-2021 & BPJS & 7 hari \\
\hline 64 & 251186 & $02-03-2021$ & 02-03-2021 & 05-03-2021 & BPJS & 1 hari \\
\hline 65 & 251189 & $02-03-2021$ & 04-03-2021 & 09-03-2021 & BPJS & 3 hari \\
\hline
\end{tabular}




\begin{tabular}{|c|c|c|c|c|c|c|}
\hline No & No RM & $\begin{array}{l}\text { Tanggal } \\
\text { Masuk }\end{array}$ & $\begin{array}{l}\text { Tanggal } \\
\text { Keluar }\end{array}$ & $\begin{array}{l}\text { Tanggal } \\
\text { Kembali }\end{array}$ & Cara Bayar & $\begin{array}{c}\text { Keterlam } \\
\text { batan }\end{array}$ \\
\hline 66 & 251192 & 02-03-2021 & 04-03-2021 & $10-03-2021$ & BPJS & 4 hari \\
\hline 67 & 142732 & 02-03-2021 & 08-03-2021 & $08-03-2021$ & BPJS & - \\
\hline 68 & 243440 & $02-03-2021$ & 04-03-2021 & 09-03-2021 & BPJS & 3 hari \\
\hline 69 & 251198 & 02-03-2021 & 05-03-2021 & 09-03-2021 & BPJS & 2 hari \\
\hline 70 & 251199 & 02-03-2021 & 05-03-2021 & $06-03-2021$ & ASURANSI & - \\
\hline 71 & 251200 & $02-03-2021$ & 04-03-2021 & 09-03-2021 & BPJS & 3 hari \\
\hline 72 & 250495 & 04-03-2021 & 06-03-2021 & $08-03-2021$ & BPJS & - \\
\hline 73 & 181838 & $02-03-2021$ & 05-03-2021 & 06-03-2021 & BPJS & - \\
\hline 74 & 251210 & $02-03-2021$ & 03-03-2021 & 06-03-2021 & UMUM & 1 hari \\
\hline 75 & 251211 & $02-03-2021$ & 08-03-2021 & 13-03-2021 & ASURANSI & 3 hari \\
\hline 76 & 250812 & 02-03-2021 & 04-03-2021 & $05-03-2021$ & BPJS & - \\
\hline 77 & 251213 & $02-03-2021$ & 07-03-2021 & $18-03-2021$ & BPJS & 9 hari \\
\hline 78 & 251148 & 02-03-2021 & 04-03-2021 & 08-03-2021 & UMUM & 2 hari \\
\hline 79 & 241542 & 02-03-2021 & $05-03-2021$ & $08-03-2021$ & BPJS & 1 hari \\
\hline 80 & 251215 & 02-03-2021 & 06-03-2021 & 08-03-2021 & BPJS & - \\
\hline 81 & 248715 & 02-03-2021 & 06-03-2021 & $14-03-2021$ & BPJS & 6 hari \\
\hline 82 & 240879 & 04-03-2021 & 06-03-2021 & 09-03-2021 & BPJS & 1 hari \\
\hline 83 & 158170 & 02-03-2021 & 04-03-2021 & $05-03-2021$ & BPJS & - \\
\hline 84 & 251161 & $02-03-2021$ & 03-05-2021 & $06-03-2021$ & ASURANSI & 1 hari \\
\hline 85 & 251216 & 02-03-2021 & 04-03-2021 & 05-03-2021 & BPJS & - \\
\hline 86 & 200715 & 03-03-2021 & 08-03-2021 & $25-03-2021$ & BPJS & 15 hari \\
\hline 87 & 210413 & 03-03-2021 & 04-03-2021 & 09-03-2021 & BPJS & 3 hari \\
\hline 88 & 251120 & 03-03-2021 & 04-03-2021 & 13-03-2021 & BPJS & 7 hari \\
\hline 89 & 250837 & 03-03-2021 & 04-03-2021 & 08-03-2021 & BPJS & 2 hari \\
\hline 90 & 251167 & 03-03-2021 & 04-03-2021 & $08-03-2021$ & BPJS & 2 hari \\
\hline 91 & 251218 & 03-03-2021 & 03-03-2021 & 06-03-2021 & UMUM & 1 hari \\
\hline 9 & & & & & & 2 hari \\
\hline 2 & 248614 & 03-03-2021 & 04-03-2021 & 08-03-2021 & LAIN-LAIN & \\
\hline
\end{tabular}

Sumber : data sekunder

\section{B. Pembahasan}

Dari data di atas terdapat 25 rekam medis yang diembalikan dengan tepat waktu dan ada 67 rekam medis yang dikembalikan dengan tepat waktu yang artinya hanya $27 \%$ dari jumlah sampel yang dikembalikan dengan tepat waktu dan $73 \%$ yang dikembalikan terlambat. Maka angka keterlambatan pengembalian rekam medis masih sangat tinggi. Masih terdapat rekam medis yang dikembalikan lebih dari 5 hari dan bahkan ada yang lebih dari 10 hari.

Dari jumlah rekam medis yang pengembaliannya tidak tepat waktu paling banyak adalah pasien rawat inap yang menggunakan BPJS karena banyaknya pasien rawat inap yang menggunakan BPJS sehingga rekam medis menumpuk dan membutuhkan waktu yang lumayan lama untuk proses pengklaiman.

Sedangkan untuk pasien umum rata rata pengembalian berkas rekam medisnya tepat waktu karena tidak perlu melalui proses pengklaiman sehingga berkas hanya melalui proses perincian dan langsung dikembalikan ke unit rekam medis.

Ketidaktepatan pengembalian rekam medis juga mempengaruhi bagian filing karena jika ada pasien yang akan kontrol postrawat inap terkadang berkas belum di kembalikan ke unit rekam medis sehingga bagian filing harus menghubungi perawat 
ruangan atau bagian pengendali untuk memastikan keberadaan rekam medis pasien tersebut dan kemudian berkas tersebut diambil dan diantarkan ke poli (Al Aufa, 2018).

Dengan begitu waktu yang digunakan bagian filing untuk mengantar berkas rekam medis ke poli kurang efektif karena harus mencari keberadaan rekam medis pasien tersebut.

\section{KESIMPULAN}

Dari hasil penelitian di unit rekam medis rumah sakit mitra siaga masih banyak berkas rekam medis yang dikembalikan tidak tepat waktu sehingga akan mempengaruhi kinerja bagian yang lain seperti di bagian assembling berkas yang dikembalikan terkadang langsung banyak sehingga petugas kewalahan untuk mengerjakannya dan petugas coding juga harus mengkode berkas yang menumpuk dan segera diinput ke simrs. Untuk bagian filing juga akan kewalahan jika berkas rekam medis pasien tidak ada di ruang filing.

Maka dari itu keterlambatan pengembalian rekam medis bisa mempengaruhi kinerja semua bagian di unit rekam medis sehingga pelayanan pasien pun bisa terganggu. Khususnya pasien yang akan kontrol post rawat inap karena jika rekam medis pasien tidak ada di ruang filing maka petugas harus mencarinya dahulu sehingga membutuhkan waktu yang lama.

\section{BIBLIOGRAFI}

Al Aufa, B. (2018). Analisis Faktor yang Berpengaruh Terhadap Ketidaktepatan Waktu Pengembalian Berkas Rekam Medis Rawat Inap di RS X Bogor. Jurnal Vokasi Indonesia, 6(2), 41-46.

Depkes, R. I. (2006). Pedoman Penyelenggaraan dan Prosedur Rekam Medis Rumah Sakit. Jakarta: Direktorat Jendral Bina Pelayanan Medik.

Endradita, G., Yudianto, A., \& Jauhari, M. A. (2019). Unproportional Health Services in Hospitals for Third Class BPJS Kesehatan Participant.

Fadhilah, H. L. (2018). tanggungjawab dokter dan rsud wijaya kusumah kuningan atas bocornya rekam medis pasien di hubungkan dengan peraturan menteri kesehatan republik indonesia no. 269/menkes/per/iii/2008 tentang rekam medis dan undangundang no. 29 tahun 2004 tentang praktik $k$. Fakultas Hukum Unpas.

Hasibuan, A. S. (2020). Faktor-Faktor Yang Mempengaruhi Keterlambatan Pengembalian Berkas Rekam Medis Rawat Jalan Di UPT Rumah Sakit Khusus Paru Tahun 2019. Jurnal Ilmiah Perekam Dan Informasi Kesehatan Imelda (JIPIKI), 5(1), 108-113.

Herfiyanti, L. (2019). Pengaruh Kelengkapan Pengisian Formulir Informed Consent Anestesi Pasien Rawat Inap Terhadap Pemenuhan Standar Nasional Akreditasi Rumah Sakit (SNARS-1) HPK 5.2 di Rumah Sakit Umum Pindad Bandung. Jurnal Teras Kesehatan, 1(2), 89-98.

Hutagaol, henni natalia, \& Sakit, perminatan manajemen rumah. (n.d.). Tugas Online Manajemen Rekam Medis.

INDONESIA, P. R. (44 C.E.). Undang-Undang Republik Indonesia Nomor 44 Tahun 2009 Tentang Rumah Sakit.

Janwarin, L. M., \& Makmun, N. (2019). Analisis Keterlambatan Pengembalian Berkas Rekam Medis di Rumah Sakit. MOLUCCAS HEALTH JOURNAL, 1(3).

Jefriany, R. S. (2017). Ketepatan waktu pengembalian berkas rekam medis rawat inap di rspau dr. Suhardi hardjolukito yogyakarta.

Kemendagri, R. I. (2009). Undang-Undang Republik Indonesia Nomor 44 Tahun 2009 
tentang Rumah Sakit. Jakarta: Departemen Kesehatan RI.

Menkes, R. I. (2008). Peraturan Menteri Kesehatan Republik Indonesia No. 269/MenKes/Per/III/2008 tentang Rekam Medis. Jakarta: Kementerian Kesehatan $R I$.

Permenkes, R. I. (2008). No 269/Menkes/Per/III/2008 tentang Rekam Medis. Jakarta: Menteri Kesehatan Reupublik Indonesia.

Winarti, S. S. (2013). Analisis Kelengkapan Pengisian dan Pengembalian Rekam Medis Rawat Inap Rumah Sakit. Jurnal Administrasi Kesehatan Indonesia, 1(4), 345-351.

(C) 2021 by the authors. Submitted for possible open access publication under the terms and conditions of the Creative Commons Attribution (CC BY SA) license (https://creativecommons.org/licenses/by$\mathrm{sa} / 4.0 /)$. 